Article

\title{
Cytotoxic Effects of Vicicitus globosus (Class Dictyochophyceae) and Chattonella marina (Class Raphidophyceae) on Rotifers and Other Microalgae
}

\section{Fook Hoe Chang}

National Institute of Water and Atmospheric Research Ltd., P.O. Box 14-901 Kilbirnie, Wellington 6241, New Zealand; E-Mail: h.chang@niwa.co.nz; Tel.: +064-4-3860300; Fax: +064-4-3862153 Academic Editor: Daniel M. Alongi

Received: 1 April 2015 / Accepted: 27 May 2015 / Published: 2 June 2015

\begin{abstract}
Cultures of Vicicitus globosus (previously Chattonella globosa) and Chattonella marina, established during the 2010 fish kill event in Mahanga Bay, Wellington Harbour, are confirmed to be cytotoxic. The aggregate potency of lipophilic cell extracts of each species were evaluated using three species each of flagellates, dinoflagellates and diatoms, and a rotifer as test organisms. The cell extract of $V$. globosus destroyed cells of all nine microalgae in a matter of a few minutes to less than $15 \mathrm{~min}$, while that of $C$. marina, destroyed all species over 10 to $30 \mathrm{~min}$. The lipophilic extract of $V$. globosus caused partial disintegration of both theca wall and cytoplasm of cells of Alexandrium catenella in a matter of minutes. This effect, however, was not observed in cells of $A$. catenella exposed to that of C. marina. Tests conducted on rotifers showed similar fast-acting trends, with animals exposed to a cell extract of $V$. globosus died in a much shorter time (Lt50 $=80 \mathrm{~min})$ than those exposed to that of $C$. marina $(20 \mathrm{~h})$.
\end{abstract}

Keywords: Chattonella marina; cytotoxic; fast-acting toxins; Vicicitus globosus; toxicity

\section{Introduction}

Vicicitus globosus (Y. Hara and Chihara) F. H. Chang and Chattonella marina (Subrahmanyan) Y. Hara and Chihara are golden brown, heterokont flagellates. Previously, both species were assigned to the class Raphidophyceae. Recent phylogenetic analyses conducted by Chang et al. 2012 [1] indicated 
that $V$. globosus is closely related to Dictyocha speculum Ehrenberg and D. octonaria Ehrenberg. Hence, this species has been transferred to the Class Dictyochophyceae.

In New Zealand, Vicicitus globosus (Figure 1A-C) has been recorded on many occasions in the Harauki Gulf, Wellington Harbour, and Marlborough Sounds ([1,2], MacKenzie pers. com.). This species has also been widely reported in the coastal waters of Japan [3,4], Southern China [5], South-East Asia, Australia, Canada [6], Greece [7], the far eastern coast of Russia [8] and Brazil [9]. Like $V$. globosus, Chattonella marina (Figure 1D) is also very widespread and has been found in New Zealand, Australia, Japan, Korea, India, Netherlands, Norway, Brazil, and the USA [2,6,10,11].

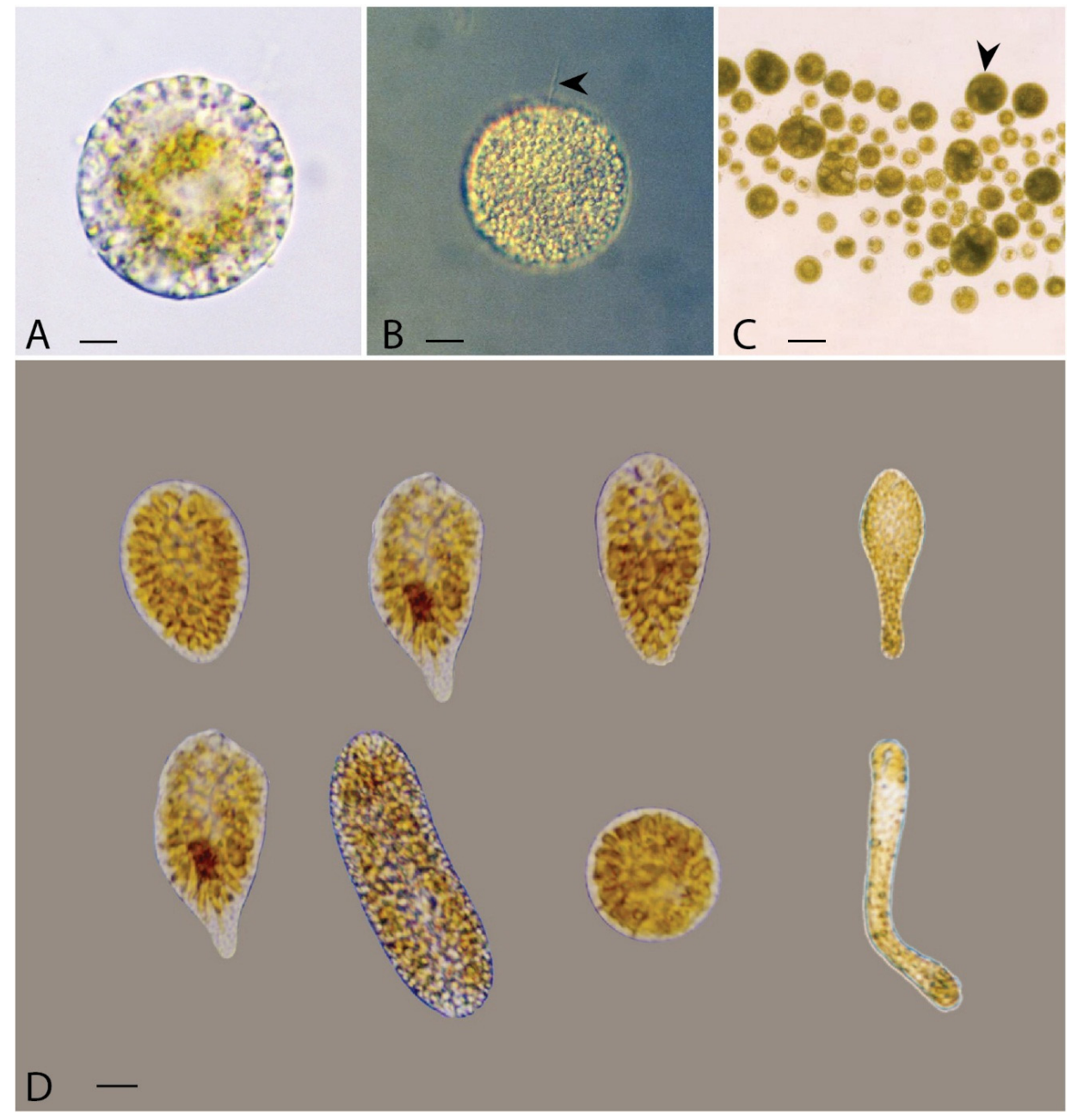

Figure 1. (A,B) vegetative cells, one showing a long flagellum (arrowhead) at the anterior end of the Vicicitus globosus cell; and (C) a mix of small, gamete-like cells and large multinucleate cells (arrowhead); (D) a range of eight different morphotypes of vegetative cells of Chattonella marina observed, from exponential to very late stationary growth phases. (scale bars of A, B $=10 \mu \mathrm{m}, \mathrm{C}=60 \mu \mathrm{m} ; \mathrm{D}=10 \mu \mathrm{m}$ ).

Both Vicicitus globosus and Chattonella marina are ichthyotoxic. As C. marina, C. antiqua (Hada) Ono and C. ovata Y. Hara and Chihara are genetically indistinguishable from each other (e.g., [12-15]) they are considered to be conspecific. In Japan, blooms of both Chattonella marina and $V$. globosus, that have occurred in coastal waters, resulted in mortality of farmed and wild fish (e.g., [3,15-18]). Thus far, fish kills attributed to only C. marina blooms have been reported in South Australia [19], Norway [11], 
and the Salton Sea of California, USA [10]. Fish killing events associated with build-up of either $V$. globosus or C. marina, however, have not yet been recorded in New Zealand.

Chattonella marina has been claimed to produce a fat-soluble toxin similar to brevetoxin (e.g., [20,21]). However, recent studies of Marshall et al. [19] and McNabb et al. [22] failed to detect the presence of significant quantities of this toxin in both the Australian and New Zealand strains. Nevertheless, this fat-soluble toxin has been suggested to be mainly responsible for the toxic effects of this species (e.g., [20,21,23]). Even though reactive oxygen species (ROS) were previously associated with fish mortalities (e.g., [24,25]), it was concluded by studies of Marshall et al. [19] that the polyunsaturated fatty acid eicosapentaenoic acid (EPA) in the presence of superoxide can account for the high fish-killing potential. Based on a comparative toxicity study of both C. marina and Karenia brevis, Shen et al. [26], however, argued that ichthyotoxins, including brevetoxin and lipophilic compounds, such as free fatty acids and hemolysins, are unlikely to be the principal toxins causing fish deaths. Very little, however, is known about ichthyotoxicity and toxins of $V$. globosus.

During the fish kill event of May 2010 in Wellington Harbour, New Zealand, Heterosigma akashiwo (Hada) Hada was found to dominate a multispecies bloom, with Karenia concordia Chang, Vicicitus globosus and Pseudochattonella cf. verruculosa as subdominant [2,27]. A very small number of Chattonella marina was also recorded after the multispecies blooms. Both $V$. globosus and C. marina were successfully cultured from the harbour during this period and provided an opportunity to evaluate the harmful effects of lipophilic cell extracts of these two species on a range of algal species and on rotifers.

\section{Materials and Methods}

\subsection{Cultures and Growth Conditions}

A small number of both Vicicitus globosus and Chattonella marina cells were collected during the June 2010 multispecies bloom (temperature $13-14^{\circ} \mathrm{C}$ ) from Wellington Harbour (41 $\left.{ }^{\circ} 17^{\prime} \mathrm{S}, 174^{\circ} 46^{\prime} \mathrm{E}\right)$ [2]. Cells of each species was individually isolated, one at a time, using a fine capillary tube and transferred into a 24-well cell culture plate (Corning Inc., New York, USA) in GSe medium (salinity 31 ppt) [28] as described in Chang et al. [27]. The established, non-axenic isolates of both $V$. globosus and C. marina were maintained at $18{ }^{\circ} \mathrm{C}$ in a constant temperature room under cool white fluorescent light $(160 \mu \mathrm{mol}$ photons $\mathrm{m}^{-2} \mathrm{~s}^{-1}$ ).

\subsection{Cell Extraction and Cytotoxicity Tests}

Ten litres each of both Vicicitus globosus (strain NIWA 1008) and Chattonella marina (strain NIWA 1022) harvested in mid-log growth phase, were used for bioactive compound extraction. Since brevetoxins and free fatty acids are lipophilic compounds, these cultures were extracted with $2 \mathrm{~L}$ of dichloromethane/methanol $(3: 1, \mathrm{v} / \mathrm{v})[29,30]$. After the addition of these solvents, the cultures were left overnight to allow separation into two phases. The upper water soluble phase of each culture, separated subsequently from the lower dichloromethane phase using a separatory funnel, was discarded and further extracted twice with dichloromethane/methanol. The combined lower solvent-soluble phase was evaporated to dryness under vacuum. The dry residue of each species was dissolved in $2 \mathrm{~mL}$ of absolute methanol and stored at $-20{ }^{\circ} \mathrm{C}$ for subsequent tests. The lipophilic extract of $V$. globosus contained 
c. $6.4 \times 10^{7}$ cells while that of C. marina contained c. $7.3 \times 10^{7}$ cells. Crude toxin extracts of $V$. globosus and C. marina were designated as $\mathrm{VgTx}$ and $\mathrm{CmTx}$, respectively.

Cytotoxicity tests were conducted on three species each of dinoflagellates, microflagellates and diatoms, and also on rotifers as described in Chang [29] and Chang and Gall [30] (Table 1). Duplicates of $2 \mathrm{~mL}$ of each algal culture in exponential growth phase were transferred into each individual well of the 24-well cell culture plate. Forty microliters of VgTx and CmTx, the lipophilic extract of a non-toxic Nannochloropsis sp. control, and absolute methanol blank, were separately mixed into $2 \mathrm{~mL}$ algal culture in each well.

Table 1. Cytotoxic effects of the lipophilic extracts of Vicicitus globosus (strain NIWA 1008) (VgTx) and Chattonella marina (strain NIWA 1022) (CmTx) on three species each of dinoflagellates, three classes of microflagellates, diatoms, and also on rotifers (Lt50 = time taken to kill half the number $(50 \%)$ of the test organisms).

\begin{tabular}{ccc}
\hline & \multicolumn{2}{c}{ Lt50 } \\
\hline Taxa & VgTx & CmTx \\
\hline Class Dinophyceae & & \\
Alexandrium catenella & $11 \mathrm{~min}$ & $25 \mathrm{~min}$ \\
Karenia concordia & $10 \mathrm{~min}$ & $20 \mathrm{~min}$ \\
Karenia mikimotoi & $12 \mathrm{~min}$ & $22 \mathrm{~min}$ \\
\hline Class Dictyochophyceae & \\
\hline Vicicitus globosus & $7 \mathrm{~min}$ & $30 \mathrm{~min}$ \\
\hline Class Raphidophyceae & \\
\hline Chattonella marina & $10 \mathrm{~min}$ & $25 \mathrm{~min}$ \\
\hline Class Cryptophyceae & & \\
\hline Rhodomonas sp. & $5 \mathrm{~min}$ & $16 \mathrm{~min}$ \\
\hline Class Bacillariophyceae & & $18 \mathrm{~min}$ \\
\hline Ditylum brightwellii & $9 \mathrm{~min}$ & $22 \mathrm{~min}$ \\
Lauderia annulata & $12 \mathrm{~min}$ & $20 \mathrm{~min}$ \\
Chaetoceros sp. & $11 \mathrm{~min}$ \\
\hline Rotifers & $80 \mathrm{~min}$ & \\
\hline
\end{tabular}

For tests on rotifers, $60 \mu \mathrm{L}$ of $\mathrm{VgTx}, \mathrm{CmTx}$, the algal and methanol blank controls were also separately added to duplicates of $2 \mathrm{ml}$ rotifer culture (each contained about 20 individuals) in each well. The methanol concentration of either the control or lipophilic extract in each well never exceeded $2 \%$ $(\mathrm{v} / \mathrm{v})$, a concentration, which had previously been shown to have no effect on the assay [29]. In this study, the time taken for half of algal cells to lyse or rotifers to die (with destruction of internal structure) was recorded as lethal time $50 \%$ or Lt50.

\section{Results}

\subsection{Effects of Lipophilic Extracts of Vicicitus globosus and Chattonella marina on Microalgal Cells}

When exposed to VgTx all nine algal species, representing five algal classes, showed a relatively short Lt50 ( $<15 \mathrm{~min}$ ) (Table 1); cells of all nine species tested (including those having protoplasts maintained within the silicate cell walls), were destroyed by lysis caused by VgTx. Moreover, VgTx 
appeared to be able to destroy cells of all three classes of microflagellates, namely Dictyochophyceae, Raphidophyceae and Cryptophyceae, faster than those of dinoflagellates and diatoms. Algal cells exposed to CmTx, however, did not respond as fast as that of VgTx. With the exception of diatoms, the Lt50 of CmTx was generally more than double (16-30 min) that of VgTx. Cells of all nine algal species, when exposed to either lipophilic extract of the non-toxic Nannochloropsis sp. control or the methanol blank, remained intact and healthy throughout the tests.

During the course of toxicological tests, only two species, Alexandrium catenella and Chattonella marina, showed distinct responses to $\mathrm{VgTx}$ and $\mathrm{CmTx}$. In the following descriptions of specific response of each species to VgTx and CmTx were separately presented here.

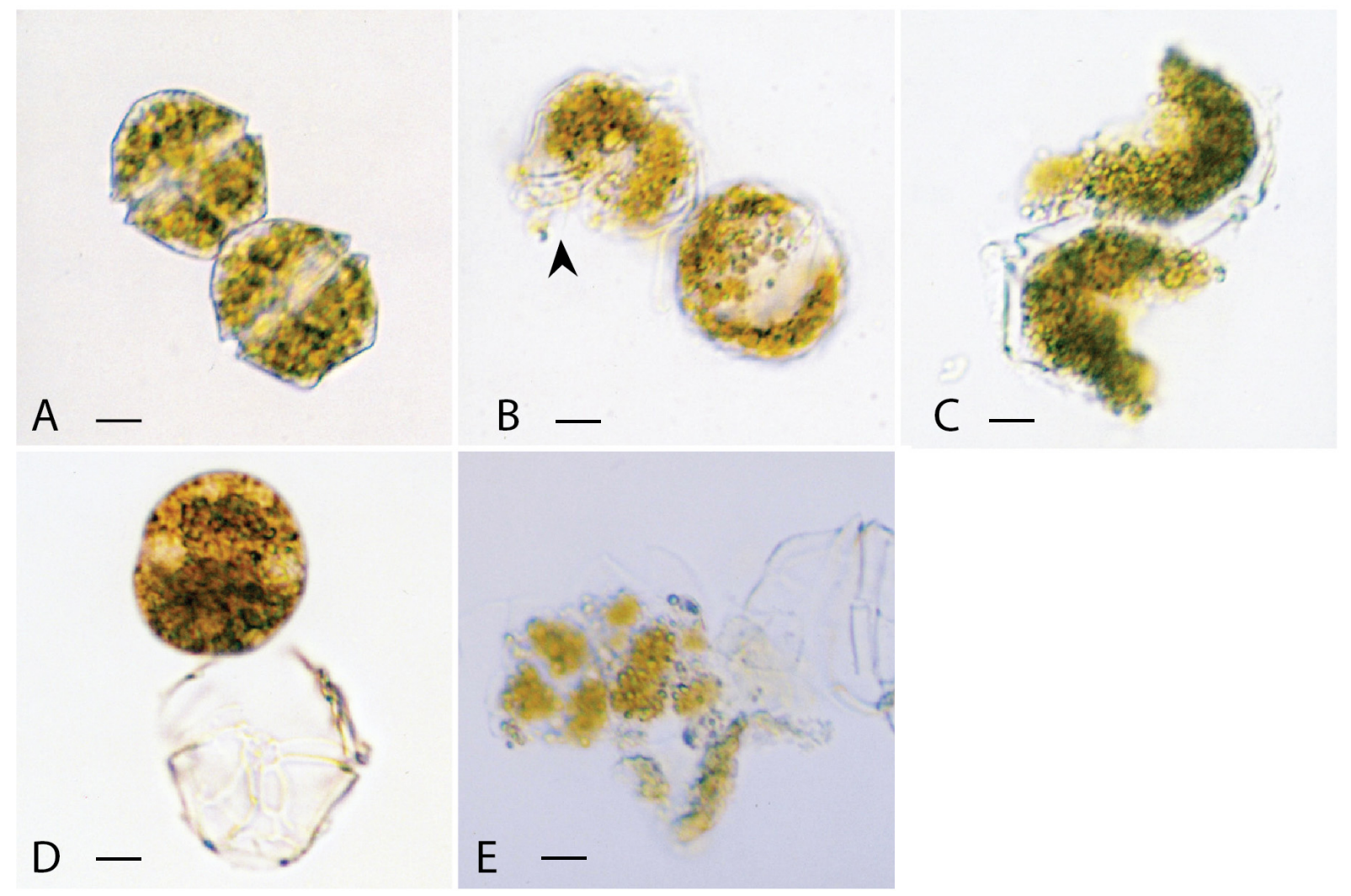

Figure 2. Light micrographs of Alexandrium catenella cells exposed to (A), methanol in the control experiment for $24 \mathrm{~h}$; (B), lipophilic extract of Vicicitus globosus (VgTx) for 2 min, showing part of the cellulose armoured plate being 'dissolved' leaving a hole (arrowhead) in the cell wall; (C), VgTx for 11 min, showing almost half of each cell in the 2-cell chain being "dissolved" away; (D), lipophilic extract of Chattonella marina (CmTx) for $10 \mathrm{~min}$, showing the enlarged protoplast being released from the theca; $(\mathbf{E}), \mathrm{CmTx}$ for $20 \mathrm{~min}$, showing the disintegrated, enlarged protoplast. (scale bars from $\mathrm{A}$ to $\mathrm{E}=5 \mu \mathrm{m}$ ).

\subsubsection{Alexandrium catenella}

A small number of $A$. catenella cells in the test culture generally existed in a two-cell chain (Figure 2A). Within $30 \mathrm{~s}$ of being exposed to VgTx, flagella of each $A$. catenella cell disintegrated, and then the two cells in the chain became detached. Within 5 min a portion of the armoured plate with cytoplasm of the thecate form started to "dissolve" away, leaving behind a big "hole" on each cell (Figure 2B). In the next 
couple of minutes, some of the partially disintegrated cells broke up into two or more pieces (Figure 2C). Approximately $50 \%$ of cells were destroyed within $11 \mathrm{~min}$.

In contrast, armoured plates of all $A$. catenella cells exposed to CmTx remained virtually intact. In the first few minutes the protoplasts held within the armoured plates rounded up; the enlarged protoplasts eventually pushed their way out of the cellulose cell walls (Figure 2D). At this point a very small number of cells with intact flagella still maintained their mobility. In $25 \mathrm{~min}$, approx. 50\% of the detached protoplasts became disintegrated (Figure 2E).

\subsubsection{Chattonella marina}

When exposed to VgTx most of the ovoid shaped Chattonella marina cells (Figure 3A) responded by rounding up in the first 2-3 min (Figure 3B). In the next few seconds a large amount of cellular material discharged from the cell. Eventually, the cell collapsed leaving a cloud of cellular material surrounding the lysed cell (Figure 3C). Approximately 50\% of C. marina cells were destroyed within 10 min of being exposed to VgTx.

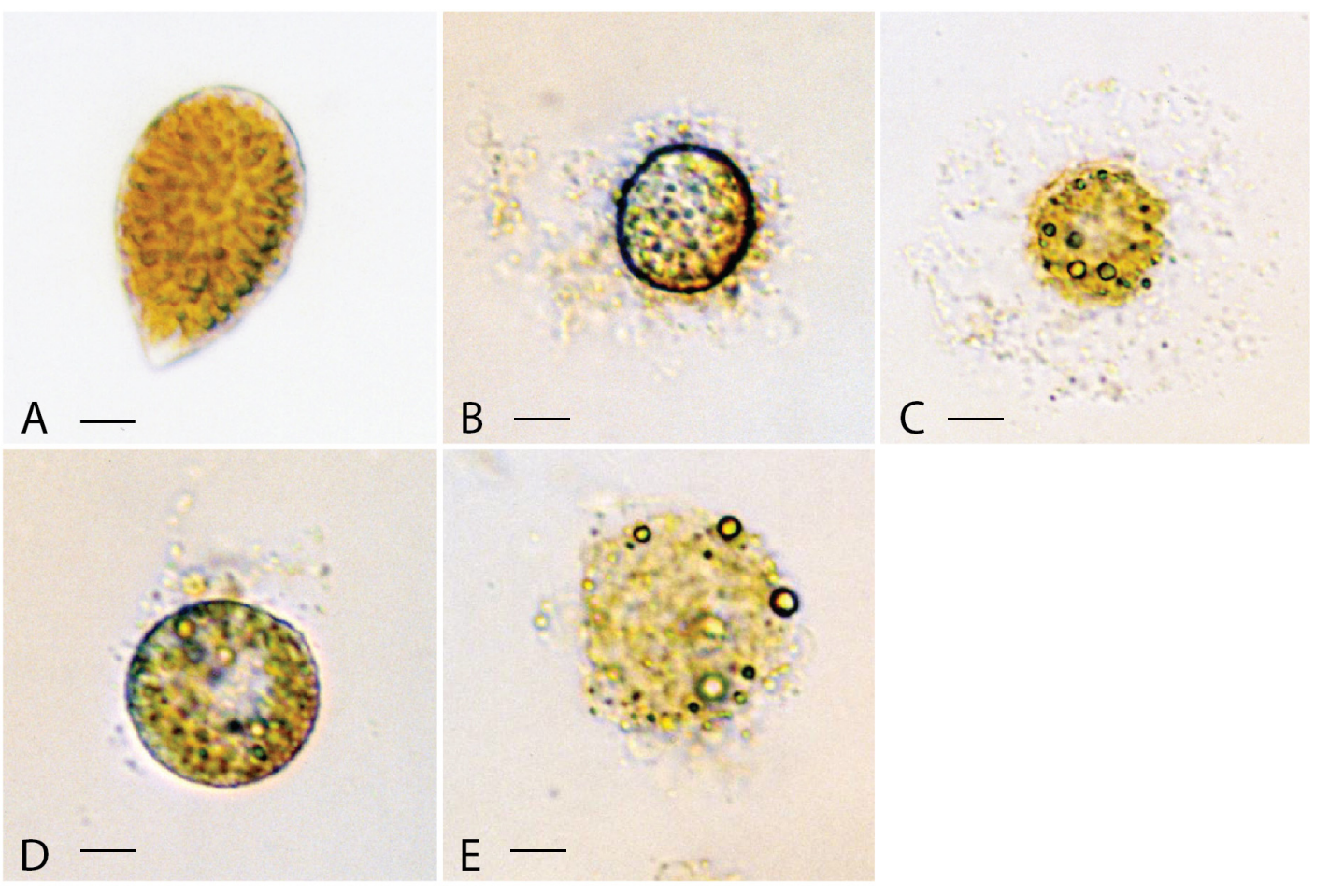

Figure 3. Light micrographs of Chattonella marina cells exposed to (A), methanol in the control experiment for $10 \mathrm{~h}$, showing a healthy cell; (B), lipophilic extract of Vicicitus globosus (VgTx) for 2 min, showing large amount of cellular materials being discharged from the cell; (C), VgTx for $5 \mathrm{~min}$, showing the collapsed cell surrounded by a cloud of cellular material; (D), lipophilic extract of Chattonella marina (CmTx) for c. $12 \mathrm{~min}$, showing a little of cellular materials being released from the cell; (E), CmTx for $20 \mathrm{~min}$, showing the collapse of a disintegrated cell. (scale bars from A to $\mathrm{E}=5 \mu \mathrm{m}$ ).

The response of Chattonella marina exposed to CmTx, however, differed slightly from those of VgTx. About $15 \%$ of cells rounded up in the first 20 min (Figure 3D). As with cells treated with VgTx, 
a small amount of cellular material discharged from the cell. About $50 \%$ of these cells lysed in $25 \mathrm{~min}$ with not very much of cellular materials being found outside the cells (Figure 3E).

\subsection{Cytotoxicity on Rotifers}

Rotifers exposed to either the lipophilic extract of non-toxic Nannochloropsis sp. or methanol blank remained healthy throughout the tests (Figure 4A). When $2 \mathrm{~mL}$ of rotifer culture in the culture well was spiked with $60 \mu \mathrm{L}$ of VgTx, within $10 \mathrm{~min}$, individual animals became motionless, and in c. $80 \mathrm{~min}$, half of them died (with internal structure destroyed and cellular materials discharged from the dead individual) (Figure 4B). In separate tests, $50 \%$ of rotifers exposed to $60 \mu \mathrm{L}$ of CmTx died in c. $20 \mathrm{~h}$ (Figure 4C).

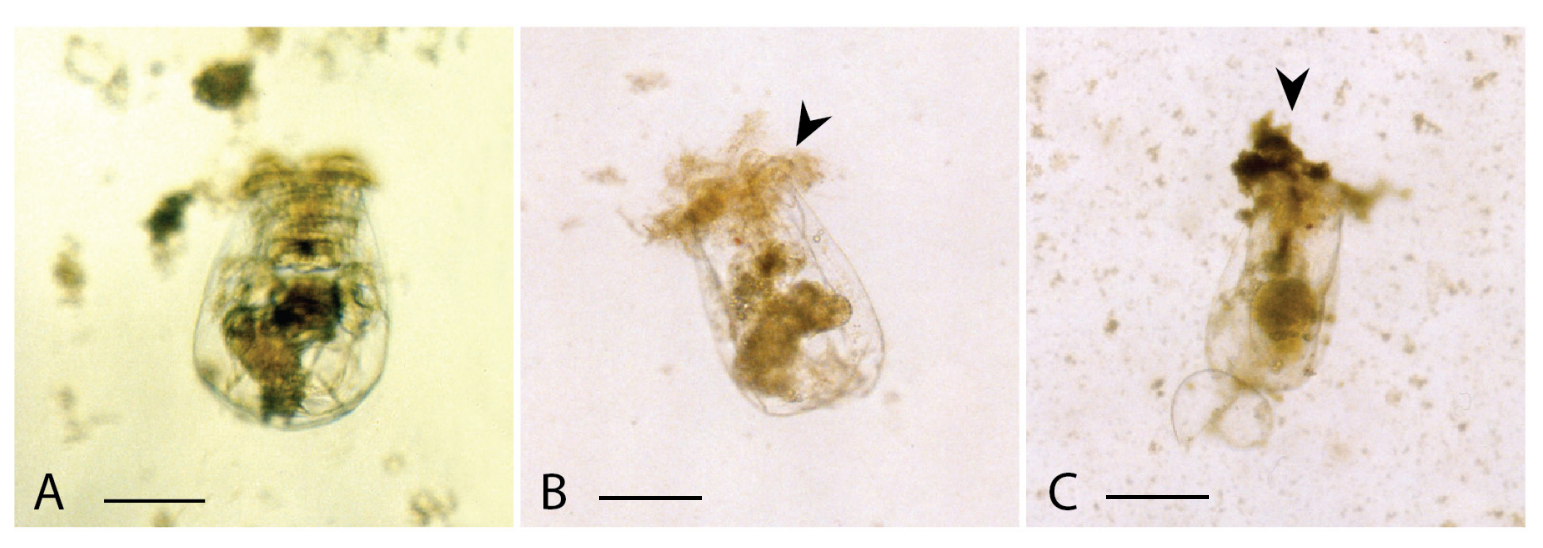

Figure 4. Light micrographs of rotifers exposed to (A), methanol in the control experiment for $24 \mathrm{~h}$, showing a healthy individual; (B), lipophilic extract of Vicicitus globosus (VgTx) for c. $80 \mathrm{~min}$, showing cellular materials being discharged from the dead individual (arrowhead); (C), lipophilic extract of Chattonella marina (CmTx) for c. $20 \mathrm{~h}$, showing cellular materials being discharged from the dead individual (arrowhead). (scale bars from A to $\mathrm{C}=100 \mu \mathrm{m}$ ).

\section{Discussion}

In this study lipophilic extracts of Vicicitus globosus and Chattonella marina were found to cause destruction and death of both algal cells and rotifers in a relatively short time, confirming that lipophilic extracts of both species are cytotoxic to all test organisms. In terms of potency, the lipophilic extract of $V$. globosus appeared to act faster than that of C. marina. Nevertheless, both toxins are more like those of Karenia concordia Chang and Ryan and K. brevisulcata (Chang) Gert Hansen and Moestrup, which are fast-acting (cultured under the same conditions and causing algal cell destruction in tens of minutes), and less like that of K. mikimotoi (Miyake and Kominami ex Oda) Gert Hansen and Moestrup (killed in matters of hours) [29].

It is quite clear that toxins produced by Vicicitus globosus and Chattonella marina killed by acting on the membrane of cells, indicating that these lipophilic extracts are hemolytic cytotoxins. These observations are consistent with those made by Dafni and Shilo [31], Gentien and Azul [32], Deeds [33], Place et al. [34], and Chang [29] on several other marine life-killing algae (e.g., Prymnesium parvum, Karlodinium veneficum (Ballatine) J. Larsen (previously K. micrum), Karenia concordia, K. brevisulcata and $K$. mikimotoi). These hemolytic cytotoxins are thought to change the permeability of the cell membrane 
to a range of ions leading to cell death through swelling and eventually osmotic lysis of cells [31,33-35]. Lipophilic extract produced by Vicicitus globosus, however, also killed by partially "dissolving" both the armoured plate and cytoplasm of the thecate Alexandrium catenella cell in a relatively short time and, thus, resembled the toxin produced by K. concordia (KcTx) [29]. Apparently this effect differs from hemolytic cytotoxins (including $\mathrm{CmTx}$ ) that cause only osmotic lysis of cells. It is, therefore, likely that the unique action of VgTx also involved an undiscovered process reminiscent of KcTx.

Lipophilic extracts of Vicicitus globosus and Chattonella marina might contain not only the principal toxins that have already been characterised but also other known or unknown bioactive compounds. Hence observations made in this study could be an aggregate response of each species to the toxins produced by both $V$. globosus and C. marina. For example, the Japanese strain of C. marina was reported to produce a fat-soluble toxin similar to brevetoxin (e.g., [21,22]), while that of the Australian and New Zealand strains of $C$. marina, had virtually no brevetoxin [19,22]. Moreover, the Australian strain also had high levels of reactive oxygen radicals and free polyunsaturated fatty acids (FFAs) (no data on the New Zealand strain) [19]. As very few studies were conducted on $V$. globosus (probably due to lack of viable cultures), not much is known about the toxins and other bioactive compounds produced by this species. The only piece of information on V. globosus, as with both the Australian and New Zealand strains of $C$. marina, is that it does not produce brevetoxin (chloroform extract of the New Zealand V. globosus analysed by A.J. Bourdelais at the University of North Carolina at Wilmington, USA, showed negative results). Given that the distinct action of $\operatorname{VgTx}$ against thecal plates of Alexandrium catenella, observed in this study, is not known to be typical of the FFA's or any of the known toxins, the involvement of an, as yet, unknown lipophilic bioactive compounds cannot be ruled out.

In conclusion, this study confirmed that lipophilic extracts of both the New Zealand strains of Vicicitus globosus and Chattonella marina, reminiscent of their overseas counterparts, are cytotoxic to all the organisms tested. Even though both VgTx and CmTx are considered to be fast-acting, the former appeared to destroy algal cells and kill rotifers a little faster than that of the latter. Moreover VgTx destroyed not only the cellulose-armoured plates of Alexandrium catenella, but also cytoplasm of the cell. No such response, however, was observed when testing with CmTx, reflecting a difference in the chemical nature of both the active compounds produced by $V$. globosus and C. marina.

\section{Acknowledgments}

The author thanks Janet Grieve of NIWA Greta Point, Wellington for her constructive criticisms of this manuscript. This work was supported by NIWA's Coasts and Oceans Research Programme 2 Marine Biological Resources (15/2014) and SIP Fund.

\section{Conflicts of Interest}

The author declare no conflict of interest. 


\section{References}

1. Chang, F.H.; McVeagh, M.; Gall, M.; Smith, P. Chattonella globosus is a member of Dictyochophyceae: Reassignment of Vicicitus gen. nov., based on molecular phylogeny, pigment composition, morphology and life history. Phycologia 2012, 51, 403-420.

2. Chang, F.H.; Mullan, A.B. Extended blooms of Karenia concordia and other harmful algae from 2009 to 2011 in Wellington Harbour, New Zealand. In Harmful Algae 2012, Proceedings of the 15th ICHA, 29 October-2 November 2012; Kim, H.G., Reguera, B., Hallegraeff, G.M., Lee, C.K., Han, M.S., Choi, J.K., Eds.; International Society for the Study of Harmful Algae: Changwon, Korea, 2014.

3. Akizuki, Y.; Kitakado, I.; Sasaki, M. Globular type of flagellates occurring at the early stage of Hornellia blooms. In Report of Previous Conjecture and Research of Red Tides in 1979; Seto Inland Sea Block: Seto, Japan, 1981; pp. 201-204.

4. Hosaka, M.; Takayama, N.; Hirai, S.; Hoda, M.; Hara, Y. The occurrence of raphidophycean alga Chattonella sp. (globular type) in Tokyo Bay, Japan. Bull. Plankton Soc. Jpn. 1991, 38, 1-8.

5. Lu, S.H.; Hodgkiss, I.J. More raphidophyte blooms in South China waters. Harmful Algae News 2001, 22, 1-2.

6. Hallegraeff, G.M.; Hara, Y. Taxonomy of harmful marine raphidophytes. In Manual of Harmful Marine Microalgae; Hallegraeff, G.M., Anderson, D.M., Cembella, A., Eds.; UNESCO Publishing: Paris, France, 2003; pp. 511-522.

7. Ignatiades, L.; Gotsis-Skretas, O. A review on toxic and harmful algae in Greek coastal waters (E. Mediterranean Sea). Toxins 2010, 2, 1019-1037.

8. Simakova, N.V.; Orlova, T.Y.; Selina, M.S. Red tide caused by raphidophytes Chattonella sp. in Amurskii Bay, the Sea of Japan. Russ. J. Mar. Biol. 1990, 16, 77-79.

9. Mafra Junior, L.L.; Fernades, L.F.; Proenca, L.A.O. Harmful algae and toxin in Paranaguá Bay, Brazil: Bases for monitoring. Braz. J. Oceanogr. 2006, 54, 1-49.

10. Tiffany, M.A.; Barlow, S.B.; Matey, V.E.; Hurlbert, S.H. Chattonella marina (Raphidophyceae), a potentially toxic alga in the Salton Sea, California. Hydrobiologia 2001, 466, 187-194.

11. Elbraechter, M. Exotic flagellates of coastal North Sea waters. Helgol. Meeresunters. 1998, 52, 235-242.

12. Sako, Y.; Otake, I.; Uchida, A. The harmful algae Chattonella antiqua, C. marina and C. ovata (Raphidophyceae). Phylogenetically the same species. In Proceedings of the HAB 2000, IX International Conference on Harmful Algal Blooms, Hobart, Tasmania, Australia, 7-11 September 2000; p. 213.

13. Bowers, H.A.; Tomas, C.; Tengs, T.; Kepton, J.W.; Lewitus, A.J.; Oldach, D.W. Raphidophyceae (Chadefaud ex Silva) systematics and rapid identification: Sequence analyses and real time PCR assays. J. Phycol. 2006, 42, 1333-1348.

14. Hosoi-Tanabe, S.; Otake, I.; Sako, Y. Phylogenetic analysis of noxious red tide flagellates Chattonella antiqua, C. marina, C. ovata, and C. verruculosa (Raphidophyceae) based on the rRNA gene family. Fish. Sci. 2006, 72, 1200-1208. 
15. Demura, M.; Noel, M.-H.; Kasao, F.; Watanabe, M.M.; Kawachi, M. Taxonomic revision of Chattonella antiqua, C. marina and C. ovata (Raphidophyceae) based on their morphological characteristics and genetic diversity. Phycologia 2009, 48, 518-535.

16. Hiroshi, S.; Okada, H.; Imai, I.; Yoshida, T. High toxicity of the novel bloom-forming species Chattonella ovata (Raphidophyceae) to cultured fish. Harmful Algae 2005, 4, 783-787.

17. Okaichi, T. Marine environmental studies on outbreaks of red tides in neritic waters. J. Oceanogr. Soc. Jpn. 1983, 39, 267-278.

18. Imai, I.; Itoh, K. Annual life cycle of Chattonella spp., causative flagellates of noxious red tides in the Inland Sea of Japan. Mar. Biol. 1987, 94, 287-292.

19. Marshall, J.-A.; Nichols, P.D.; Hamilton, B.; Lewis, R.J.; Hallegraeff, G.M. Ichthyotoxicity of Chattonella marina (Raphidophyceae) to damselfish (Acanthochromis polycanthus): The synergistic role of reactive oxygen species and free fatty acids. Harmful Algae 2003, 2, 273-281.

20. Onoue, Y.; Nozawa, K. Separation of toxins from harmful red tides occuring alone the coast of Kagoshima Prefecture. In Red Tides: Biology, Environmental Science and Toxicology; Okaichi, T., Anderson, D.M., Nemoto, T., Eds.; Elseier: New York, NY, USA, 1989; pp. 371-374.

21. Khan, S.; Ahmed, M.S.; Arakawa, O.; Onoue, Y. Properties of neurotoxins separated from harmful red tide organism Chattonella marina. Israeli J. Aquac.-Bamidgeh 1995, 47, 137-141.

22. McNabb, P.; Rhodes, L.; Adamson, J.; Holland, P. Brevetoxin-An elusive toxin in New Zealand waters. Afr. J. Mar. Sci. 2006, 28, 375-377.

23. Endo, M.; Onoue, Y.; Kuroki, A. Neurotoxin-induced cardiac disorder and its role in the death of fish exposed to Chattonella marina. Mar. Biol. 1992, 112, 371-376.

24. Shimada, M.; Murakami, T.H.; Imahayashi, T.; Ozaki, H.S.; Toyoshima, T.; Okaichi, T. Effects of sea bloom, Chattonella antiqua, on gill primary lamellae of the young yellowtail, Seriola quinqueradiatta. Acta Histochem. Cytochem. 1983, 16, 232-244.

25. Oda, Y.; Nakamura, A.; Shimada, M.; Kawano, I.; Ishimatsu, A.; Muramatsu, T. Generation of reactive oxyen species by raphidophycean phytoplankton. Biosci. Biotechnol. Biochem. 1997, 61, 1658-1662.

26. Shen, M.; Xu, J.; Tsang, T.Y.; Au, D.W.T. Toxicity comparison between Chattonella marina and Karenia brevis using marine medaka (Oryzias melastigma): Evidence against the suspected ichthyotoxins of Chattonella marina. Chemosphere 2010, 80, 585-591.

27. Chang, F.H.; Sutherland, J.E.; McVeagh, M.; Gall, M. Molecular phylogeny, pigment composition, toxicology and life history of Pseudochattonella cf. verruculosa (Class Dictyochophyceae) from Wellington Harbour, New Zealand. Harmful Algae 2014, 34, 42-55.

28. Blackburn, S.I.; Hallegraeff, G.M.; Bolch, C.J. Vegetative reproduction and sexual life cycle of the toxic dinoflagellate Gymnodinioum catenatum from Tasmania. Aust. J. Phycol. 1989, 25, 577-590.

29. Chang, F.H. Toxic effects of three closely-related dinoflagellates, Karenia concordia, K. brevisulcata and K. mikimotoi (Gymnodiniales, Dinophyceae) on other microalgal species. Harmful Algae 2010, 10, 81-187.

30. Chang, F.H.; Gall, M. Pigment compositions and toxic effects of three harmful Karenia species, Karenia concordia, Karenia brevisulcata and Karenia mikimotoi (Gymnodiniales, Dinophyceae), on rotifers and brine shrimps. Harmful Algae 2013, 27, 113-120. 
31. Dafni, Z.; Shilo, M. The cytotoxic principle of the phytoflagellate Prymnesium parvum. J. Cell Biol. 1966, 28, 464-471.

32. Gentien, P.; Arzul, G. Exotoxin production by Gyrodinium cf. aureolum (Dinophyceae). J. Mar. Biol. Assoc. UK 1990, 70, 571-581.

33. Deeds, J.R. Toxins and Toxicity from the Cosmopolitan, Bloom-Forming Dinoflagellate Karlodinium micrum. Ph.D. Thesis, University of Maryland, Centre of Marine Biotechnology, College Park, MD, USA, 2003; p. 247.

34. Place, A.R.; Bowers, H.A.; Bachvaroff, T.R.; Adolf, J.E.; Deeds, J.R.; Sheng, J. Karlodinium veneficum - The little dinoflagellate with a big bite. Harmful Algae 2012, 14, 179-195.

35. Shilo, M. Toxins of Chrysophyceae. In Microbial Toxins; Kadis, S., Ciegler, A., Aj1, S.J., Eds.; Academic Press: New York, USA, 1980; Volume 7, pp. 67-103.

(C) 2015 by the authors; licensee MDPI, Basel, Switzerland. This article is an open access article distributed under the terms and conditions of the Creative Commons Attribution license (http://creativecommons.org/licenses/by/4.0/). 